\title{
THE ATTITUDINAL LEGACY OF COMMUNIST LABOR RELATIONS
}

\author{
DAVID G. BLANCHFLOWER and RICHARD B. FREEMAN*
}

This study of workers' attitudes compares data from International Social Survey Programme (ISSP) surveys for former communist countries in Europe with ISSP data for Western countries over the period 1987-93, which covers the beginning of the transition to a market economy for the former communist countries. Consistent with their hypothesis that communist-run economies left an attitudinal "legacy," the authors find that the citizens of former communist countries evinced a greater desire for egalitarianism, less satisfaction with their jobs, and more support for strong trade unions and state intervention in the job market and economy than did Westerners. Over the course of the period studied, however, residents of the former communist European countries perceived sizable increases in occupational earnings differentials, and they adjusted their views of the differentials that "ought to" exist in their economies in the direction of greater inequality.

$\mathbf{L}$ abor relations in communist economies has diverged historically from that in free market economies. Under communism nearly all workers joined official "transmission belt" unions that operated as an arm of the state rather than as independent representatives of workers. The state set wages, prices, and enterprise budgets in ways that created huge job vacancies with

*David Blanchflower is Professor of Economics at Dartmouth College and Research Associate at the National Bureau of Economic Research. Richard Freeman is Professor of Economics at Harvard University, Director of Labor Studies at the National Bureau of Economic Research, and Director of the Programs in Discontinuous Economics at the London School of Economics. The authors thank Alan Krueger for helpful suggestions on an earlier draft of this paper. no open unemployment, and produced low real wages and narrow skill and sectoral pay differentials. These practices resulted in inefficient allocations of labor (Freeman 1992). At the same time, there was a social ethos favoring egalitarianism (Burawoy 1985; Kornai 1980). While most analysts believe that communist labor practices produced demoralized and disgruntled workers, there have been no comparisons of worker attitudes in historically communist economies and market economies using comparable survey instruments that document or test this expectation. ${ }^{1}$

\footnotetext{
'Three papers have used attitudinal data to examine the development of markets in general, but not specifically labor markets, in eastern Europe. Akerlof and Yellen (1991) looked at various attitudes of workers in East Germany and comparable workers in West
} 
To what extent do workers in traditionally communist societies differ from workers in the West in their attitudes toward working conditions, wage inequality, job satisfaction, and the role of unions and the state in determining labor market outcomes? To what extent can any observed differences be attributed to the "legacy" of the communist past? How have attitudes changed during the transition to a market economy?

In this study we use data from the International Social Survey Programme (ISSP) to try to answer those questions. ${ }^{2}$ Each year the ISSP focuses on a particular topic. The topics most relevant to our area of inquiry are "social inequality" (the 1992 and 1987 modules), "work orientation" (the 1989 module, supplemented by preliminary evidence from the 1993 module),$^{3}$ and "the role of government" (1990). ${ }^{4}$ We have information on seven ex-communist countries: Bulgaria, Czechoslovakia, East Germany, Hungary, Poland, Slovenia, and Russia. Most of these countries reported in the 1992 module. For Hungary and Poland, we

Germany, Shiller et al. (1991) compared random samples of the Moscow and New York populations in their attitudes toward free markets. In another paper, Shiller et al. (1992) studied individual attitudes in three ex-communist countries-Russia, Ukraine, and East Germany-and compared them with individual attitudes in three advanced capitalist economies-the United States, Japan, and West Germany. In addition, Rose and Haerpfer (1994) contrasted attitudes toward the transformation of ex-communist societies, and Frentzel-Zagorska and Zagorski (1993) examined Polish opinion concerning privatization and state interventionism.

${ }^{2}$ The ISSP is a continuing program of cross-national collaboration carried out by a group of national research institutes, each of which conducts an annual survey of social attitudes and values. It brings together pre-existing national social science surveys and coordinates their research to produce a common set of questions asked in identical form in the participating nations.

${ }^{3}$ We refer to this evidence as preliminary because it is taken from means for the survey published by the ISSP. The computer files were not available for analysis at the time of our study.

${ }^{4}$ For earlier work using these data, see Blanchflower and Freeman (1992) and Blanchflower and Oswald $(1989,1994)$. have information in several ISSP modules, which allows us to analyze changes in labor outcomes and attitudes over time. Appendix Table A1 reports the number of responses by country and year.

\section{Measuring The Communist Legacy in the Labor Market}

Like any other lengthy historical experience, decades of communist rule in eastern Europe and Russia have arguably left a "legacy" of effects on workers and the job market that successor market economies must deal with. There is a potential labor market outcome legacy: narrow wage distributions; distinct work practices (Haraszti 1978; Burawoy and Lukacs 1992); relations with management that diverge from those in historically capitalist economies (Burawoy 1985; Kornai 1980); high rates of union membership in unions dominated by communist regimes; dependence of firms on the state; and enterprise provision of many social benefits. In addition, there is a potential "attitudinal legacy" in terms of workers' views about institutions and markets due to experience under communism and decades of communist propaganda.

To be sure, institutions, labor market outcomes, and attitudes are likely to differ among ex-communist countries, just as they do among Western countries. Poland and Hungary differ in the nature of their former communist systems and in the characteristics of their movement to a market economy, just as Sweden and Norway differ from the United States and the United Kingdom. National differences notwithstanding, however, the operative hypothesis of this study is that the communist experience was sufficiently similar to leave an identifiable common legacy affecting outcomes and views of the labor market in the ex-communist states. This is a hypothesis about cross-national differences due to comparable experiences, and as such is subject to the problems of assessment common to such analyses (Kohn 1989).

A priori, what form might this legacy take? By imposing narrow wage distributions through governmental fiat, and pressing 
an egalitarian ethos, communism should have influenced attitudes toward earnings inequality and government interventions in labor market outcomes. We anticipate three differences in attitudes between workers in ex-communist and Western countries: (1) employees in ex-communist countries will be more favorable toward narrow wage distributions and government interventions to attain them; (2) given the persistence of poor working conditions in former communist countries (in which workers were deprived of normal market modes of responding to such conditions, having neither the "exit" option of finding employment outside the state-run sector nor the "voice" option of forming free trade unions), employees in those countries will evince less job satisfaction than workers in Western countries; and (3) workers in excommunist countries will have more positive attitudes toward free trade unions than do workers in the West. In addition, assuming that attitudes toward inequality respond to actual levels of inequality, we expect that the views in ex-communist countries toward wage differences will change over time, as competitive markets produce greater inequality.

We examine the ISSP for evidence of such "legacies" in two ways. First, we contrast responses to ISSP questions (both outcome and attitude items) in ex-communist countries with those in Western countries, controlling for respondents' individual characteristics. This is effectively an exercise in estimating country dummy variables: the test of the legacy hypothesis is whether there is a common pattern among the dummy variables for ex-communist countries. Second, we probe the correlates and investigate possible objective causes for any observed differences. This is an effort to explain differences between excommunist countries and Western countries in terms of actual or perceived labor market factors.

In attitude surveys, the validity and reliability of measures are invariably of some concern. Because none of our data are longitudinal, we cannot determine whether the same person would respond similarly to the same question in a second interview, which would give us test-retest measurement errors. This does not mean, however, that we have no way to assess the quality of responses. We perform three checks on individual responses: (1) we examine whether individual responses fit a patternfor instance, whether workers who are completely satisfied with their jobs also express more willingness than others to work without pay; (2) we relate individual responses to objective characteristics: are workers who want a more narrow wage distribution high or low in that distribution?; and (3) we investigate whether people with the same characteristics give comparable responses in different surveys. The results of all of these checks suggest that responses on the ISSP are consistent. ${ }^{5}$

\section{Characteristics of ex-Communist and Western Data Samples}

For our cross-section analyses of workers in ex-communist economies and market economies, we rely heavily on the 1992 ISSP, which provides data on seven ex-communist countries (Bulgaria, the Czech Republic, East Germany, Hungary, Poland, Russia, and Slovenia) supplemented by the 1993 ISSP. For our analysis of changes over time, we use the 1987 and 1992 ISSP surveys, which contain comparable information for Hungary and Poland. None of these data files are ideal. Relatively few

\footnotetext{
${ }^{5}$ As examples of our checks, we found that $24 \%$ of those completely satisfied with their job agreed strongly that they would work without pay, compared to less than $10 \%$ of those who were dissatisfied, $13 \%$ who were neither satisfied nor dissatisfied, and so on. Also, we confirmed that greater inequality was favored by the more educated (see Table 2 ) and those with high earnings (table available from authors on request); we found, from a comparison of responses on similar questions in 1987 and 1992, that years of schooling had a comparable effect in both years (see coefficients reported in Table 2); and we confirmed that age, sex, and marital status also had comparable effects in both years. In addition, we explored individual differences in responses to the Table 7 questions and found that people with similar demographic characteristics responded in the same direction.
} 
workers in the ISSP for the ex-communist countries report being in the private sector, which prevents us from making inferences about differences between those employees, who will constitute the bulk of future employment, and employees of stateowned firms. For our comparison group we have data from eleven OECD countries in 1987 or 1992 (Australia, Austria, Canada, Great Britain, Italy, Netherlands, New Zealand, Norway, Switzerland, West Germany, and the United States) plus information on other variables of interest on six other countries (Israel, Japan, the Philippines, Southern Ireland, Spain, and Sweden) in other years of the ISSP. ${ }^{6}$

We compare the former communist states with a set of Western countries rather than with a single one because differences between the eastern European countries and any particular Western country, such as the United States, could be due to the distinct characteristics of that Western country rather than to the legacy of communist labor practices vis-à-vis market economies in general. The danger of this approach, however, is that we may miss important contrasts between more narrowly defined groups, say between East Germany and West Germany. To deal with this danger, we present all calculations with individual country dummies before giving broader excommunist versus traditional market economy contrasts.

\section{Attitudes Toward Inequality}

As a starting point for analyzing differences in views toward inequality between persons in ex-communist economies and those in traditional capitalist economies, we examined responses to the 1992 ISSP

${ }^{6}$ In a number of cases the data were collected in a different year from that reported. For example, Great Britain did not conduct a survey in 1988; the reported data were collected in 1989 . Half the 1989 respondents were asked the questions from the 1988 ISSP and the other half were asked the questions from the 1989 component. In a few cases, such as Italy in 1988, 1989, 1990, and 1991 and Austria in 1987 and 1988 , the same group of respondents were asked the two years of questions. question: "Are differences in income in this country too large?" The difference between the ex-communist countries and the West is stark. ${ }^{7}$ Save for Italy, there is only the barest overlap in the survey responses. On average, $52 \%$ of respondents in the ex-communist countries expressed a strong belief that income differences were too large, compared to $30 \%$ of respondents in Western countries. Most striking, perhaps, are the differences between citizens in the ex-communist countries and those in Scandinavia, where incomes are more equally distributed than in most capitalist economies and where the social democratic egalitarian ethos is strong. In Sweden and Norway, just $23-24 \%$ of respondents believed income differences were too large.

We pursue the analysis of differences in views toward inequality across countries using two questions on the 1987 and 1992 ISSPs on pay by occupation. In those years the ISSP asked individuals in different countries "what people earn each year" and what they "ought to earn" in 11 occupations. In each of the two years, seven of these occupational groups were identical, while four were different. ${ }^{8}$ We used the reported figures on what people earn to estimate a measure of "perceived differentials" and used the reported figures on what they ought to earn to estimate "appropriate differentials." ${ }^{9}$ We calculated from these re-

${ }^{7}$ The percentages agreeing strongly that differences in income were too large were as follows: Bulgaria, $85 \%$; East Germany $61 \%$; Russia, $59 \%$; Slovenia, $48 \%$; Poland, $42 \%$; Czech Republic, $36 \%$, Hungary $35 \%$; Italy, 53\%; Great Britain, 37\%, Austria, 35\%, West Germany, $31 \%$, New Zealand, $30 \%$, United States, $28 \%$, Canada, $26 \%$; Sweden, $24 \%$; Norway, $23 \%$; and Australia, $18 \%$.

${ }^{8}$ The occupational categories available in both years were doctor, small shopkeeper, chairman of large national company, skilled factory worker, farm worker, unskilled factory worker, and cabinet minister. In 1987 the remaining four categories were bricklayer, bank clerk, secretary, and bus driver, whereas in 1992 they were replaced by solicitor, shop assistant in a department store, owner/manager of a factory, and appeal court judge.

${ }^{9}$ Summaries of the mean earnings by country in the two categories are reported in a data appendix that is available on request from the authors. 
sponses the standard deviation of the natural $\log$ of the averages reported in these appendix tables for each country.

The resultant statistic does not measure what survey respondents believe occupational differentials should be. They were not asked about occupational differentials per se, but rather about occupational pay. But implicit in statements about pay for different occupations are statements about differentials in pay. For instance, someone who reports that the chairman of a large national company earns or should earn X while a bricklayer earns or should earn $\mathrm{Y}$ is telling us about the differentials he perceives to exist or believes should exist. The legacy hypothesis suggests that persons in ex-communist countries should differ from those in capitalist countries both in the occupational differentials they perceive to exist and in the differentials they believe to be fair (that is, the differentials they believe "ought to" exist).

Table 1 gives the standard deviations of the natural log of earnings from the 1987 and 1992 ISSP modules. ${ }^{10}$ In 1987 , workers in the two ex-communist countries for which we have data, Hungary and Poland, perceived smaller occupational differentials than did workers in most Western countries. The unweighted country mean for Hungary and Poland in the standard deviation of perceived differentials is, for example, 0.57 , which falls considerably short of the 0.81 for workers in the West and the

\footnotetext{
${ }^{10} \mathrm{We}$ also calculated the standard deviation of the log of wages or (where wages were unavailable) earnings in reporting countries from the 1987 and 1992 ISSP surveys. The only ex-communist country for which earnings data exist for 1987 is Hungary: its measure of inequality is below that of all the capitalist countries except West Germany. For the year 1992, we have data on all of the ex-communist countries in our sample. In the ex-communist sample, Hungary turns out to be among the low inequality countries, while Russia, Slovenia, and Poland have higher standard deviations of log earnings. Among the capitalist countries, Norway and Italy join Germany as low inequality countries. Overall, inequality was still higher in 1992 in the ex-communist countries.
}

0.85 for those in the four large ex-communist countries for which we have data in both 1987 and 1992 (the United States, West Germany, Great Britain, and Italy). The second column in the table shows a similar ex-communist/Western difference in the pattern of occupational pay differentials that people believe ought to exist: persons in the ex-communist states favor smaller differentials than persons in the West. In the 1987 data, the average standard deviation of the natural log of earnings perceived to be fair is 0.40 for Hungary and Poland, compared to an average of 0.60 in the capitalist countries.

By contrast, in 1992, when the transition to a market economy was under way, persons in Hungary and Poland and in the other ex-communist countries for which we have data reported very different perceptions of pay differentials. The differentials they perceived were wider than those perceived by respondents in the Western countries in the ISSP (which includes Norway, with an extremely narrow wage distribution) and similar to those perceived by workers in the big ex-communist countries. Similarly, what Hungarians and Poles believed "ought to" be paid to workers in different occupations was much greater in 1992 than in 1987. Because the "ought to" differentials are also high for workers in the other ex-communist countries, the unweighted mean of the standard deviation of the natural log of earnings perceived to be fair is in the same range for employees in the ex-communist countries as for those in the West: it is slightly higher than the unweighted mean for all Western countries (inclusive of Norway) and slightly lower than the mean for the larger excommunist countries.

In both years, and in all countries, excommunist and capitalist, there seems to be a relation between the distribution of perceived pay and the distribution of pay perceived to be fair. The "ought to" differentials are invariably smaller than the perceived differentials, suggesting that workers may form their views of the appropriate pay by occupation on the basis of perceived pay, scaling the latter down by some amount. 
Table 1. Perceptions of Actual Earnings and Fair Earnings Across 11 Occupations: Responses of Those Surveyed in Six Ex-Communist and Eleven Capitalist Countries, 1987 and 1992.

(Mean Standard Deviation of Log Earnings)

\begin{tabular}{|c|c|c|c|c|}
\hline Country & $\begin{array}{c}1987 \\
\text { Perceived } \\
\text { Earnings }\end{array}$ & $\begin{array}{c}1987 \\
\text { Earnings Viewed } \\
\text { as Fair }\end{array}$ & $\begin{array}{c}1992 \\
\text { Perceived } \\
\text { Earnings }\end{array}$ & $\begin{array}{c}1992 \\
\text { Earnings Viewed } \\
\text { as Fair }\end{array}$ \\
\hline \multicolumn{5}{|l|}{ Ex-Communist } \\
\hline Bulgaria & & & .77 & .53 \\
\hline Czechoslovakia & & & 1.35 & 1.07 \\
\hline East Germany & & & 1.03 & .78 \\
\hline Hungary & .59 & .41 & .94 & .67 \\
\hline Poland & .54 & .38 & 1.02 & .68 \\
\hline Russia & & & 1.09 & .71 \\
\hline Unweighted Mean & .57 & .40 & 1.03 & .74 \\
\hline \multicolumn{5}{|l|}{ Capitalist } \\
\hline $\begin{array}{l}\text { Australia } \\
\text { Austria }\end{array}$ & $\begin{array}{l}.55 \\
.95\end{array}$ & $\begin{array}{l}.43 \\
.64\end{array}$ & .84 & .69 \\
\hline Canada & & & .81 & .63 \\
\hline Great Britain & .84 & .61 & .99 & .76 \\
\hline Italy & & & .91 & .77 \\
\hline $\begin{array}{l}\text { Netherlands } \\
\text { New Zealand }\end{array}$ & .74 & .59 & & \\
\hline $\begin{array}{l}\text { New Zealand } \\
\text { Norway }\end{array}$ & & & $\begin{array}{l}.81 \\
.59\end{array}$ & $\begin{array}{l}.01 \\
.37\end{array}$ \\
\hline Switzerland & .85 & .65 & & \\
\hline United States & .88 & .68 & 1.19 & .83 \\
\hline West Germany & .84 & .60 & 1.05 & .79 \\
\hline Unweighted Mean & .81 & .60 & .90 & .68 \\
\hline BIG G7 (US, WG, GB, It) & .85 & .63 & 1.04 & .79 \\
\hline
\end{tabular}

Source: ISSP (1987, 1992). Calculated from data shown in Appendix Tables A1 and A2.

For a list of the occupations covered, see text.

Perceived differentials increase between 1987 and 1992, and so too do "ought to" differentials. Countries with high perceived differentials have high "ought to" differentials.

To explore the relation between "ought to" and perceived occupational pay, we calculated individual-specific measures of perceived and "ought to" occupational earnings differentials. Specifically, for each person in the samples, we calculated the standard deviation of that respondent's perception of actual earnings across occupations and the standard deviation of the earnings he or she believes "ought to" be paid across those occupations. These statistics differ from the statistics in Table 1. In Table 1 we calculated standard deviations for the natural log of mean earnings across occupations within a country (one value per country). Our new statistic is based on the standard deviation of the natural log of earnings across occupations reported by each individual (one value for each individual).

We then estimated ordinary least squares regressions of these individual measures of perceived and desired inequality on personal characteristics, such as schooling, age, gender, and country dummy variables, with the United States as the reference group. By including variables for individual characteristics, we perform ceteris paribus comparisons of people in the ex-communist countries and in the West and examine the relation between personal characteristics and perceived/"ought to" pay differentials. Since the group of countries covered in 1987 differs from that covered in 1992, we provide separate calculations for the two 
years. To summarize the ex-communist countries/Western countries differentials of concern, we also estimated a restricted model in which we replaced the individual country dummies with the single summary dummy variable that takes the value 1 for an ex-communist country and 0 for the Western countries. Finally, to test inferences about changes over time, we further estimated our model on a pooled sample limited to countries that appear in both years.

Table 2 presents the basic cross-section regression results. There are three findings. First, consistent with Table 1, column 1 of Table 2 shows that, controlling for personal characteristics, in 1987 persons in ex-communist countries perceived lower occupational pay differentials than did respondents in the West, save for those in Australia. Column 2 shows that the Hungarians and Poles also believed that the differentials "ought to" be less than did respondents in the West, including the Australians. The coefficients on schooling further show that persons with more potential earnings power also perceived greater differentials and were more likely to believe that such differentials were fair.

Column 3 adds the standard deviation of the natural log of perceived differentials to the "ought to" equation. What does this tell us? It shows what people in different countries believe the spread in occupational pay should be, conditional on the spread they perceive. For instance, the coefficient on the dummy for Hungary of -.0574 shows that, taking account of the lower perceived spread in earnings, Hungarians still desired a smaller spread than did persons in the excluded United States.

The coefficients on the standard deviation of perceived earnings are overwhelmingly statistically significant. This implies that people's attitudes toward the spread of earnings that "ought to" be paid are formed not in a vacuum but in fact depend upon what they see in the marketplace. The 0.62 coefficient implies, roughly, that individuals believe the distribution of occupational differentials in their country "ought to" be scaled down from what they perceive it to be by a factor of 0.62 .

For example, if the standard deviation of the natural log of perceived occupational earnings was 0.64 (the mean value in our sample in 1992), the estimated coefficient implies, ceteris paribus, individuals would like earnings differentials that would yield a standard deviation of 0.57 (the standard deviation of perceived pay of 0.92 multiplied by 0.62 ). Conditional on perceived differentials, persons in Hungary and Poland favored a modestly more egalitarian distribution than those in Western countries: the ex-communist dummy variable in the restricted regression is just-.02, though highly significant.

Columns 3-6 of the table confirm the more complicated pattern for 1992. Perceived differentials vary considerably, with dummies for the ex-communist countries showing that workers in most countries perceived less inequality than did persons in the United States (the big exception being Russia), but more than in Norway. The summary measure shows that the excommunist dummy is a positive .10 , due in large part to the low perceived inequality in Norway among the western countries. The regression for the spread in earnings that "ought to" be paid in column 5 shows a similar pattern, but in this case workers in all the ex-communist countries, including Russia, have lower "ought to" differentials than in the United States. The coefficient on the dummy variable for ex-communist countries in the summary regression is 0.0277 .

This finding might lead some to believe that people in the ex-communist countries have less desire for narrowing pay differentials than do people in the West. But our hypothesis is that egalitarian desires are tempered by perceived market differentials. Thus the appropriate equation to assess the desires is equation (6). Here the dummy variables for the ex-communist countries are smaller than those in all Western countries except Norway, and the dummy variable in the summary regression is -0.029 , with a t-statistic of 8.19 . The similarity to the 1987 coefficient is impres- 


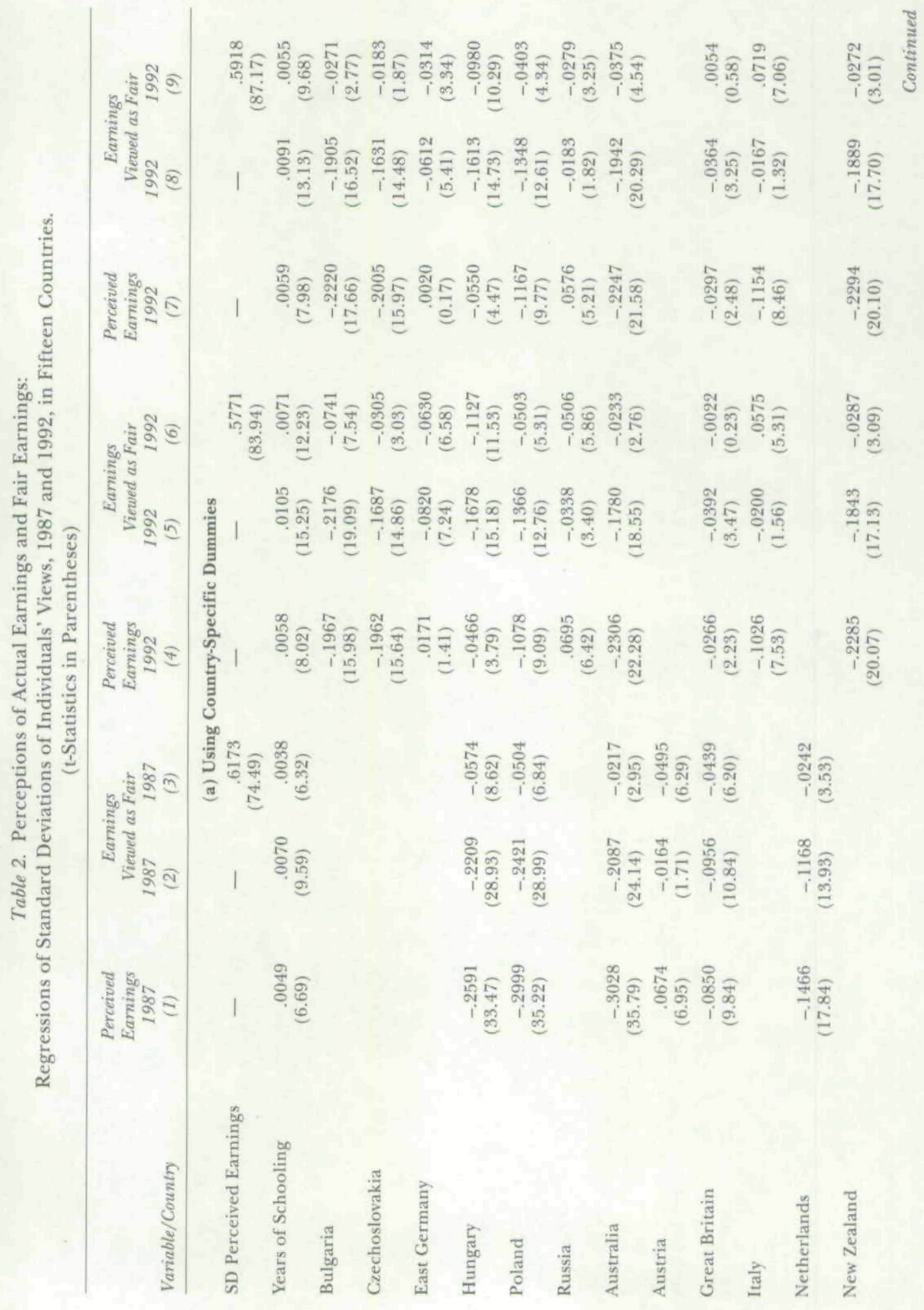




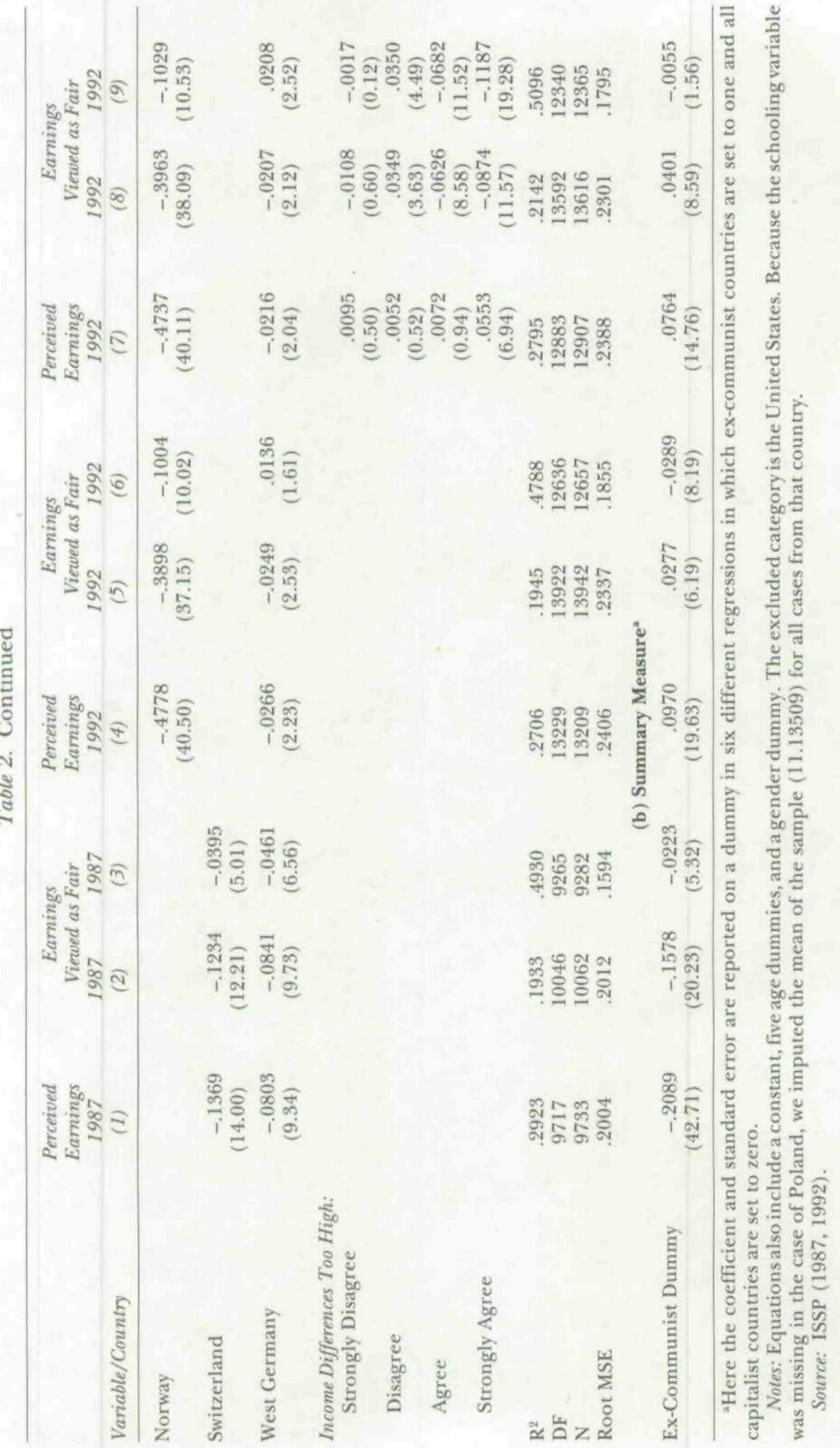


sive, suggesting that the column (3) and (6) results represent a more stable pattern than the column (2) and (5) results.

How do the findings square with those reported earlier based on the broader question of the percentages who agree strongly that differences in income are too large? If the responses to the occupational earnings questions and the responses to the "Are differences in income too large?" question are capturing the same attitudes, we would expect that including the responses to the latter in the equations for the spread of "ought to" pay should greatly weaken the dummy variables for the ex-communist countries. Column 7 shows that this is indeed the case. The coefficients on virtually all of the country dummy variables decline, and the summary measure for excommunist states drops to a bare -0.0055 , which is not significantly different from zero. The underlying reason for the negative coefficient in column (6) is thus the broad desires for lower income differences.

Overall, the implication of Table 2 is that individuals in the ex-communist countries more strongly desired a narrowing of pay differentials than did those in the West, but that they substantially tempered that desire in the light of rising differentials during the transition to a market economy. The data on which the regressions reported in Table 2 are based, however, differ across the two years both in the mix of countries included and in the set of occupations for which earnings were reported. To make a firmer assessment of changes over time, and guarantee that any measured changes over time are not due to changes in the composition of our samples, we formed a pooled sample of observations for individuals in the ex-communist countries and for those in the Western countries that reported in both years. This sample, which contains just two ex-communist countries, Hungary and Poland, and just four Western countries, the United States, Great Britain, Australia, and West Germany, provides a relatively clean picture of changes over time. To capture the changes, we include dummy variables for interactions between country and year. The dummy variable for 1992 is included to capture actual changes across the years as well as differences in the samples of occupations between the two years.

Table 3 gives our pooled regression results. The dummy variables for Hungary and Poland in column 1 show that in 1987 perceived differentials were lower in those two countries than in the West. The 1992 country interaction terms show that the differentials rose by about 0.20 natural $\log$ points over the five-year period. The regression coefficients for the 1992 interactions also show rises in perceived differentials in Western countries, but by smaller magnitudes. To obtain the perceived differentials in 1992, we must sum the coefficients on country and country-year interactions. The results of that analysis show that perceived differentials in Hungary and Poland differed little from those in Great Britain and Germany, were smaller than in the United States, and were larger than in Australia.

The spread of "ought to" differentials in column 2 reveals a general upward trend in the differentials respondents believe "ought to" be paid: the 1992 interaction terms are positive. The upward trend is weaker in Hungary but not in Poland than in the Western countries: the coefficients on the country-year dummy variable of .0473 for Hungary suggest a smaller perceived increase than in the United States (the 1992 dummy of .0869 reflects the United States) or in the other Western countries, whereas for Poland, the .0997 coefficient is comparable to that for the United States and larger than those for other Western countries.

The bottom line calculations are in Table 3 , where we estimate the coefficients on country dummy variables, conditional on the spread in perceived differentials. In 1987 people in both Poland and Hungary had a lower spread in "ought to" differentials than those in the United States or Australia. But their spread is similar to that among people in Great Britain and Germany. The sum of the coefficients on the country terms and the country-year interaction terms for 1992 shows that the spread in pay across occupations that was believed to 
Table 3. Perceptions of Actual Earnings and Fair Earnings in Five Countries: Pooled Regressions, 1987 and 1992.

(t-Statistics in Parentheses)

\begin{tabular}{|c|c|c|c|}
\hline Variable/Country & $\begin{array}{l}\text { Perceived } \\
\text { Earnings } \\
\qquad(I)\end{array}$ & $\begin{array}{c}\text { Earnings Viewed } \\
\text { as Fair } \\
\text { (2) }\end{array}$ & $\begin{array}{c}\text { Earnings Viewed } \\
\text { as Fair } \\
\text { (3) }\end{array}$ \\
\hline SD Perceived Earnings & - & - & $\begin{array}{c}.5992 \\
(86.28)\end{array}$ \\
\hline Years of Schooling & $\begin{array}{l}.0068 \\
(9.02)\end{array}$ & $\begin{array}{r}.0101 \\
(12.49)\end{array}$ & $\begin{array}{c}.0057 \\
(9.92)\end{array}$ \\
\hline Hungary & $\begin{array}{c}-.2556 \\
(30.89)\end{array}$ & $\begin{array}{l}-.2156 \\
(26.31)\end{array}$ & $\begin{array}{c}-.0592 \\
(8.43)\end{array}$ \\
\hline Poland & $\begin{array}{l}-.2973 \\
(32.73)\end{array}$ & $\begin{array}{c}-.2380 \\
(26.60)\end{array}$ & $\begin{array}{l}-.0530 \\
(6.85)\end{array}$ \\
\hline Australia & $\begin{array}{c}-.2992 \\
(32.25)\end{array}$ & $\begin{array}{l}-.2019 \\
(21.86)\end{array}$ & $\begin{array}{l}-.0225 \\
(2.93)\end{array}$ \\
\hline Great Britain & $\begin{array}{l}-.0835 \\
(9.03)\end{array}$ & $\begin{array}{l}-.0924 \\
(9.76)\end{array}$ & $\begin{array}{l}-.0431 \\
(5.65)\end{array}$ \\
\hline West Germany & $\begin{array}{l}-.0765 \\
(8.36)\end{array}$ & $\begin{array}{l}-.0778 \\
(8.42)\end{array}$ & $\begin{array}{l}-.0432 \\
(5.73)\end{array}$ \\
\hline 1992 Dummy & $\begin{array}{c}.1466 \\
(14.99)\end{array}$ & $\begin{array}{c}.0869 \\
(9.13)\end{array}$ & $\begin{array}{l}-.0248 \\
(3.02)\end{array}$ \\
\hline Hungary*1992 & $\begin{array}{l}.2115 \\
(15.51)\end{array}$ & $\begin{array}{l}.0473 \\
(3.65)\end{array}$ & $\begin{array}{l}-.0547 \\
(4.83)\end{array}$ \\
\hline Poland*1992 & $\begin{array}{c}.1922 \\
(13.97)\end{array}$ & $\begin{array}{c}.0997 \\
(7.57)\end{array}$ & $\begin{array}{l}.0011 \\
(0.09)\end{array}$ \\
\hline Australia*1992 & $\begin{array}{l}.0688 \\
(5.42)\end{array}$ & $\begin{array}{l}.0210 \\
(1.66)\end{array}$ & $\begin{array}{l}.0004 \\
(0.04)\end{array}$ \\
\hline Great Britain*1992 & $\begin{array}{c}.0571 \\
(4.07)\end{array}$ & $\begin{array}{l}.0506 \\
(3.60)\end{array}$ & $\begin{array}{c}.0379 \\
(3.29)\end{array}$ \\
\hline West Germany*1992 & $\begin{array}{c}.0579 \\
(4.50)\end{array}$ & $\begin{array}{l}.0517 \\
(4.07)\end{array}$ & $\begin{array}{l}.0533 \\
(5.01)\end{array}$ \\
\hline $\begin{array}{l}\mathrm{R}^{2} \\
\mathrm{DF} \\
\mathrm{N} \\
\text { Root MSE }\end{array}$ & $\begin{array}{r}.3761 \\
13960 \\
13979 \\
.2151\end{array}$ & $\begin{array}{r}.2314 \\
14628 \\
14647 \\
.2218\end{array}$ & $\begin{array}{r}.5077 \\
13324 \\
13343 \\
.1723\end{array}$ \\
\hline
\end{tabular}

Notes: Equations also include five age dummies and a gender dummy. The excluded category is the United States. Because the schooling variable was missing for Poland, in all cases for that country we imputed the mean for the other countries.

Source: ISSP $(1987,1992)$.

be "fair" was smaller for Hungarians and Poles than for Americans or other Westerners, conditional on the perceived spread.

We conclude that respondents in the excommunist countries had a greater preference for narrowing occupational earnings, conditional on perceived earnings, than did Westerners, but that the difference in preferences diminished greatly as perceived differentials widened in those countries more rapidly than they did in most Western countries.

\section{Job Satisfaction, Happiness and the Role of Trade Unions}

Because Hungary has been in the ISSP since 1986 , we have available more information on outcomes and attitudes for that country than for the other ex-communist 
countries. The 1989 ISSP asked questions about job satisfaction and working conditions. The 1990 ISSP asked questions about unionism. Although we are leery about generalizing from a single country to all excommunist countries, the differences in attitudes between Hungarian employees and those in Western countries do provide insight into the potential legacy of communism. They allow us to examine the widely held view that communist labor relations practices produced less desirable workplace conditions and less satisfied workers than free market practices. (See Haraszti 1978; for a contrasting view, however, see Burawoy and Lukacs 1992.)

Respondents to the 1989 ISSP were asked the generic (and widely used) job satisfaction question, "How satisfied are you in your job?" Questions about job satisfaction are difficult to interpret due to the subjective nature of the variable and problems in making interpersonal comparisons (Freeman 1978). Still, econometric analyses based on satisfaction data have yielded interesting and consistent results across data sets that show links between satisfaction and economic and demographic variables, and also show that job satisfaction is a good predictor of future quit behavior-indeed, in many longitudinal surveys, the best such predictor (see, for example, Hamermesh 1977; Borjas 1979; Freeman 1978; Blanchflower and Oswald 1992; and Clark and Oswald 1997).

What is more troubling for our analysis is that people in one country may "scale" responses differently from those in another (see Hofstede 1985 for studies of different country responses to satisfaction-type questions in a single multinational). For instance, Americans may be relatively optimistic, with an "everything will work out" mentality that leads them to respond more positively than a comparable British group to the question "Are you satisfied with your job?" even though their true satisfaction, on some objective scale, ${ }^{11}$ is the same as that

\footnotetext{
"One objective scaling would be to determine how satisfaction responses map into labor turnover.
}

of the (possibly more reserved) British. We deal with this problem by examining answers to more objective questions regarding workplace conditions-such as health and safety conditions-and estimating an ordered probit model in which we include as controls responses to other unrelated questions that might index national patterns of response.

In any case, relatively few Hungarians reported being very satisfied or completely satisfied $(13 \%)$ with their jobs compared to Westerners, among whom the proportion ranged from $33 \%$ in Eire to $50 \%$ in the United States. ${ }^{12}$ At face value, this confirms the notion that workers under communism are less satisfied than workers under capitalism.

Table 4 presents evidence on worker perceptions of objective workplace conditions that might explain the low job satisfaction reported by Hungarian workers. It shows that Hungarian workers are far less likely to regard their jobs as interesting than are Western workers (question 1) and far more likely to see their workplace as involving dangerous conditions (question 2) and unhealthy conditions (question 3). All of these perceptions are likely to feed into low job satisfaction. To the extent that they reflect objective conditions, they suggest that the reported lower job satisfaction has some grounding in reality.

As our final check on the effect of communist labor relations on job satisfaction, we use the entire distribution of responses on the 1989 job satisfaction question to estimate the difference in job satisfaction between Hungarian workers and Western

\footnotetext{
Satisfaction correlates well with quit behavior, so if the same response led to similar quitting across countries, we could view responses as valid indicators of one form of objective behavior. However, we do not have data contrasting satisfaction and quits across countries.

${ }^{12}$ The proportions of workers who reported being "very" or "completely" satisfied with their jobs were as follows: Hungary, 13\%; Ireland, 33\%; Italy, 34\%; Israel, 37\%; Great Britain, $39 \%$; Netherlands, $39 \%$; Norway, $43 \%$; West Germany, $44 \%$; Austria, $48 \%$; and the United States, $50 \%$.
} 
Table 4. Employees' Perceptions of Their Work and Working Conditions, 1989:

Respondents in Hungary Compared to Those in Eleven Capitalist Countries. ${ }^{\star}$

\begin{tabular}{lc}
\hline & $\begin{array}{c}\text { Unweighted } \\
\text { Mean of } \\
\text { Responses in } \\
\text { Capitalist } \\
\text { Response } \\
\text { Cungary }\end{array}$ \\
\hline
\end{tabular}

(Q1) "My job is interesting" -

Employed Respondents Only (1989: V63)

$\begin{array}{lcc}\text { Strongly Agree } & 6.6 & 25.7 \\ \text { Agree } & 60.4 & 49.5 \\ \text { Neither } & 20.4 & 15.3 \\ \text { Disagree } & 10.8 & 6.7 \\ \text { Strongly Disagree } & 1.5 & 2.8 \\ \text { N } & 603 & 6296\end{array}$

(Q2) "How often do you work in dangerous conditions?" - Employed Respondents Only (1989: V72)

$\begin{array}{lcr}\text { Always } & 15.8 & 3.6 \\ \text { Often } & 13.0 & 6.4 \\ \text { Sometimes } & 16.3 & 17.7 \\ \text { Hardly Ever } & 10.8 & 18.7 \\ \text { Never } & 44.2 & 53.9 \\ \text { N } & 602 & 6273\end{array}$

(Q3) "How often do you work in unhealthy conditions?" - Employed Respondents Only (1989: V73)

\begin{tabular}{lrr} 
Always & 10.3 & 3.8 \\
Often & 9.8 & 6.4 \\
Sometimes & 17.6 & 18.4 \\
Hardly Ever & 12.4 & 19.5 \\
Never & 49.9 & 51.8 \\
$\mathrm{~N}$ & 602 & 6206 \\
\hline
\end{tabular}

${ }^{2}$ For a list of countries, see Table 1 or text. Source: ISSP (1989).

workers in an ordered probit model. Ordered probits are the appropriate statistical procedure where, as in this case, respondents express their preferences in the form of an ordinal ranking.

Our model includes various demographic variables that are known to influence job satisfaction, including gender, age, and marital status. We also include a unionism variable, which previous studies have found is negatively correlated with satisfaction (Freeman 1978; Borjas 1979), and self-employment, which has been found to be positively related to satisfaction (Blanchflower and Oswald 1993). In this analysis, the coefficient on this dummy variable tells us how the entire distribution of job satisfaction differs between Hungarians and Westerners, conditional on the diverse control variables.

Table 5 presents our results. Column 1 gives a basic job satisfaction equation. It shows that the "control variables" have their expected effects on job satisfaction. Thus, the ISSP question on job satisfaction gives results comparable to those in other surveys: unionism, in particular, is negatively related to job satisfaction, while self-employment is positively related. The coefficient on the Hungary dummy is large, negative, and statistically significant (-.53).

Column 2 controls, as best we can, for income, on the hypothesis that Hungarians may be less satisfied with their job not because of any legacy of communist labor relations but simply because they are lower paid than Western workers. For this purpose, we use an ISSP question that asked people whether they viewed their income as high: "For each of the following statements about your job, please tick one box to show how much you agree or disagree that it applies to your job: My income is high."

Consistent with lower income in former communist countries, Hungarians were far more likely than Western workers to disagree with this statement. Some $70 \%$ of Hungarians disagreed or disagreed strongly that their income was high, compared to $48 \%$ of the British, $27 \%$ of Germans, $33 \%$ of Italians, $43 \%$ of Americans, and comparable fractions of other Westerners. Workers who report that their income is low are less likely to be satisfied (that is, the coefficients on the various categorical responses are increasingly negative compared to the omitted group of persons who strongly agree that their income is high). The coefficient on the Hungary dummy falls to -.41 upon addition of the "income is high" responses, 
Table 5. Correlates of Job Satisfaction, 1989:

Ordered Probits.

\begin{tabular}{|c|c|c|c|c|c|c|}
\hline \multirow[b]{2}{*}{ Variable } & \multicolumn{2}{|c|}{ (1) } & \multicolumn{2}{|c|}{ (2) } & \multicolumn{2}{|c|}{ (3) } \\
\hline & Coefficient & $\begin{array}{c}\text { Standard } \\
\text { Error }\end{array}$ & Coefficient & $\begin{array}{l}\text { Standard } \\
\text { Error }\end{array}$ & Coefficient & $\begin{array}{c}\text { Standard } \\
\text { Error }\end{array}$ \\
\hline Hungary Dummy & -.5315 & .0471 & -.4149 & .0479 & -.3211 & .0500 \\
\hline Male & -.1207 & 0271 & -.2015 & .0277 & -.1271 & .0296 \\
\hline Self-Employed & .3242 & .0468 & .3249 & .0476 & .2334 & .0487 \\
\hline Married & .0207 & .0298 & .0011 & .0302 & -.0190 & .0308 \\
\hline Age & .0100 & .0011 & .0091 & .0012 & .0066 & .0012 \\
\hline Years of Schooling & .0002 & .0044 & -.0089 & .0045 & -.0356 & .0047 \\
\hline Union Status & -.0958 & .0279 & -.1030 & .0281 & -.0708 & .0288 \\
\hline \multicolumn{7}{|l|}{ "My income is high" } \\
\hline Agree & & & -.2247 & .0813 & -.1495 & .0832 \\
\hline Neither Agree Nor Disagree & & & -.5683 & .0791 & -.3626 & .0814 \\
\hline Disagree & & & -.8650 & .0792 & -.5869 & .0917 \\
\hline Strongly Disagree & & & -1.2801 & .0872 & -.9870 & .0895 \\
\hline Can't Choose & & & -.4569 & .1641 & -.1730 & .1730 \\
\hline \multicolumn{7}{|l|}{ "My job is interesting" } \\
\hline Agree & & & & & -.5806 & .0353 \\
\hline Neither Agree Nor Disagree & & & & & -1.2294 & .0482 \\
\hline Disagree & & & & & -1.5457 & .0621 \\
\hline Strongly Disagree & & & & & -2.1059 & .0978 \\
\hline Can't Choose & & & & & -1.0886 & .2808 \\
\hline \multicolumn{7}{|l|}{ "Dangerous conditions" } \\
\hline Often & & & & & -.1899 & .0848 \\
\hline Sometimes & & & & & -.0442 & .0764 \\
\hline Hardly Ever & & & & & -.1519 & .0777 \\
\hline Never & & & & & -.1096 & .0752 \\
\hline \multicolumn{7}{|l|}{ "Unhealthy conditions" } \\
\hline Often & & & & & .0647 & .0868 \\
\hline Sometimes & & & & & .1185 & .0775 \\
\hline Hardly Ever & & & & & .2159 & .0786 \\
\hline Never & & & & & .4109 & .0756 \\
\hline Threshold 1 & -2.2709 & .0911 & -3.2536 & .1238 & -4.2908 & .1553 \\
\hline Threshold 2 & -1.9239 & .0818 & $-2,8934$ & .1165 & -3.8575 & .1469 \\
\hline Threshold 3 & -1.3500 & .0759 & -2.2885 & .1117 & -3.1390 & .1411 \\
\hline Threshold 4 & -.7704 & .0741 & -1.6779 & .1100 & -2.4310 & .1391 \\
\hline Threshold 5 & .5209 & .0739 & -.3192 & 1089 & -.8877 & .1373 \\
\hline Threshold 6 & 1.4285 & .0751 & .6355 & .1091 & .1621 & .1370 \\
\hline Number of Observations & 6399 & & 6346 & & 6312 & \\
\hline $\mathrm{Chi}^{2}(7)$ & 307.40 & & 844.94 & & 2133.24 & \\
\hline Pseudo $\mathrm{R}^{2}$ & 0.0170 & & 0.0471 & & .1194 & \\
\hline Log Likelihood & -8907.4522 & & -8555.3416 & & -7866.71 & \\
\hline
\end{tabular}

Note: The sample consists of employed respondents only. Source: ISSP (1989).

"The excluded category is "strongly agree."

"The excluded category is "always." 
but it remains substantial and significant. At similar perceptions of income (if not similar incomes), Hungarians are less satisfied with their jobs than Westerners. Finally, column 3 includes a series of dummy variables to distinguish whether respondents considered their jobs to be "interesting" or their working conditions to be "unhealthy" or "dangerous" (as in Table 4). The inclusion of these variables reduces the size of the coefficient on the Hungary dummy by approximately a quarter, although the coefficient remains statistically significant. These factors contribute to the low levels of satisfaction in Hungary, but they are not the whole story. All told, we interpret the ordered probits as confirming the reported lower job satisfaction of Hungarians with evidence about objective features of workplaces.

In addition to evidence on job satisfaction, we have reports of overall happiness by respondents, whether employed, unemployed, or out of the labor force. Since work is such an important part of life, we expect that this measure of attitudes ought also to be related to labor market experiences. Our "happiness" measure also has one important advantage over job satisfaction: it covers all citizens, including the jobless. The 1991 ISSP provides data on perceived "happiness" for Slovenia, Poland, and East Germany, as well as for Hungary and Western countries. Respondents were asked: "If you were to consider your life in general these days, how happy or unhappy would you say you are, on the whole?" Four options were given for their replies-"not at all," "not very," "fairly," and "very."13 Thirty-eight percent of Hungarians, 23\% of East Germans, and $45 \%$ of Slovenes said

${ }^{13}$ Overall, the responses were as follows (\%):

\begin{tabular}{lcrcrr} 
& $\begin{array}{c}\text { Not } \\
\text { at All }\end{array}$ & $\begin{array}{c}\text { Not } \\
\text { Very }\end{array}$ & Fairly & Very & $\begin{array}{c}\text { No. } \\
\text { Obs. }\end{array}$ \\
\hline All & 3 & 15 & 60 & 22 & 17967 \\
Capitalist & 2 & 9 & 62 & 27 & 12832 \\
Ex-Communist & 5 & 30 & 56 & 9 & 5135 \\
\hline
\end{tabular}

they were not at all happy or not very happy, compared to $11 \%$ of West Germans, $8 \%$ of the British, $8 \%$ of Americans, $7 \%$ of the Irish, $10 \%$ of New Zealanders, and $11 \%$ of Norwegians. Only the Italians and Israelis had "not at all" or "not very" happy percentages close to those of the eastern Europeans $-22 \%$ for Italians and Israelis.

Table 6 reports a series of ordered probit equations to estimate country effects on happiness, controlling for age, gender, marital status, and years of schooling. Once again we report results including a full set of country dummies (the excluded country is the United States) as well as the results from an equation that replaces the country dummies with a single ex-communist dummy. Individuals in the ex-communist countries reported being less happy than those in the Western countries in our sample. As can be seen from column 1, the lowest levels of happiness among the Western countries were to be found in Israel and Italy. The young, married individuals, women, and those with higher levels of schooling reported the highest levels of happiness.

In order to obtain results comparable to the job satisfaction evidence presented above, which was for workers only, in columns 2 and 3 we restrict the samples to the employed and those unemployed or out of the labor force, respectively. The pattern of results, including the country dummy structure, is remarkably similar to the job satisfaction pattern. In column 4 , where two dummies are added to control for labor market status, we confirm the earlier finding of Oswald (1994) that the unemployed are less happy than the employed (the excluded category). This negative unemployment result is further confirmed in columns 5 and 6 of Table 6 , where we report separate estimates for the 11 capitalist countries and the 4 ex-communist countries. ${ }^{14}$ The main differences between these two equations are the lack of significance of the

\footnotetext{
${ }^{14}$ The excluded countries are the United States and Hungary, respectively.
} 
Table 6. Reported Happiness in Capitalist and Ex-Communist Countries, 1991: Ordered Probits.

\begin{tabular}{|c|c|c|c|c|c|c|}
\hline Variable/Country & $\begin{array}{l}A l l \\
(1)\end{array}$ & $\begin{array}{l}\text { Employed } \\
\text { (2) }\end{array}$ & $\begin{array}{c}\text { Not } \\
\text { Employed } \\
\text { (3) }\end{array}$ & $\begin{array}{l}\text { All } \\
\text { (4) }\end{array}$ & $\begin{array}{c}\text { Capitalist } \\
\text { (5) }\end{array}$ & $\begin{array}{c}\text { Ex- } \\
\text { Communist } \\
\text { (6) }\end{array}$ \\
\hline Male & $\begin{array}{l}-.0933 \\
(5.14)\end{array}$ & $\begin{array}{l}-.0980 \\
(4.09)\end{array}$ & $\begin{array}{l}-.1418 \\
(4.66)\end{array}$ & $\begin{array}{l}-.0960 \\
(5.11)\end{array}$ & $\begin{array}{l}-.1232 \\
(5.37)\end{array}$ & $\begin{array}{l}-.0403 \\
(1.22)\end{array}$ \\
\hline Age 25-34 & $\begin{array}{l}-.1901 \\
(5.58)\end{array}$ & $\begin{array}{l}-.1748 \\
(4.02)\end{array}$ & $\begin{array}{l}-.2785 \\
(4.85)\end{array}$ & $\begin{array}{l}-.2068 \\
(6.04)\end{array}$ & $\begin{array}{l}-.2025 \\
(5.10)\end{array}$ & $\begin{array}{l}-.2181 \\
(3.18)\end{array}$ \\
\hline Age $35-44$ & $\begin{array}{l}-.2742 \\
(7.56)\end{array}$ & $\begin{array}{l}-.2888 \\
(6.32)\end{array}$ & $\begin{array}{l}-.3113 \\
(4.91)\end{array}$ & $\begin{array}{l}-.3003 \\
(8.22)\end{array}$ & $\begin{array}{l}-.2844 \\
(6.64)\end{array}$ & $\begin{array}{l}-.3406 \\
(4.79)\end{array}$ \\
\hline Age $45-54$ & $\begin{array}{l}-.2727 \\
(7.09)\end{array}$ & $\begin{array}{l}-.2930 \\
(6.01)\end{array}$ & $\begin{array}{l}-.2774 \\
(4.27)\end{array}$ & $\begin{array}{l}-.3037 \\
(7.85)\end{array}$ & $\begin{array}{l}-.2898 \\
(6.34)\end{array}$ & $\begin{array}{l}-.3376 \\
(4.55)\end{array}$ \\
\hline Age 55-64 & $\begin{array}{l}-.2738 \\
(6.86)\end{array}$ & $\begin{array}{l}-.2823 \\
(4.80)\end{array}$ & $\begin{array}{l}-.2277 \\
(3.82)\end{array}$ & $\begin{array}{l}-.2994 \\
(7.39)\end{array}$ & $\begin{array}{l}-.2921 \\
(6.06)\end{array}$ & $\begin{array}{l}-.3087 \\
(3.89)\end{array}$ \\
\hline Age $65-74$ & $\begin{array}{l}-.1158 \\
(2.63)\end{array}$ & $\begin{array}{l}.1367 \\
(1.19)\end{array}$ & $\begin{array}{l}-.0869 \\
(1.43)\end{array}$ & $\begin{array}{l}-.1373 \\
(3.00)\end{array}$ & $\begin{array}{l}-.0839 \\
(1.59)\end{array}$ & $\begin{array}{l}-.2994 \\
(3.16)\end{array}$ \\
\hline Married & $\begin{array}{l}.3659 \\
(13.24)\end{array}$ & $\begin{array}{l}.3532 \\
(10.22)\end{array}$ & $\begin{array}{l}.3816 \\
(8.14)\end{array}$ & $\begin{array}{l}.3547 \\
(12.81)\end{array}$ & $\begin{array}{l}.3670 \\
(11.35)\end{array}$ & $\begin{array}{l}.3004 \\
(5.48)\end{array}$ \\
\hline Widowed & $\begin{array}{l}-.2261 \\
(4.75)\end{array}$ & $\begin{array}{l}-.1457 \\
(1.77)\end{array}$ & $\begin{array}{l}-.2440 \\
(3.77)\end{array}$ & $\begin{array}{l}-.2385 \\
(5.00)\end{array}$ & $\begin{array}{l}-.2129 \\
(3.71)\end{array}$ & $\begin{array}{l}-.3299 \\
(3.77)\end{array}$ \\
\hline Divorced/Separated & $\begin{array}{l}-.2604 \\
(5.88)\end{array}$ & $\begin{array}{l}-.2208 \\
(3.86)\end{array}$ & $\begin{array}{l}-.3068 \\
(4.31)\end{array}$ & $\begin{array}{l}-.2584 \\
(5.83)\end{array}$ & $\begin{array}{l}-.2548 \\
(4.84)\end{array}$ & $\begin{array}{l}-.3133 \\
(3.73)\end{array}$ \\
\hline Years of Schooling & $\begin{array}{l}.0253 \\
(8.48)\end{array}$ & $\begin{array}{l}.0215 \\
(5.51)\end{array}$ & $\begin{array}{l}.0270 \\
(5.53)\end{array}$ & $\begin{array}{l}.0229 \\
(7.63)\end{array}$ & $\begin{array}{l}.0175 \\
(4.91)\end{array}$ & $\begin{array}{c}.0377 \\
(6.70)\end{array}$ \\
\hline West Germany & $\begin{array}{l}-.3661 \\
(7.74)\end{array}$ & $\begin{array}{l}-.3574 \\
(5.89)\end{array}$ & $\begin{array}{l}-.3819 \\
(5.00)\end{array}$ & $\begin{array}{l}-.3748 \\
(7.92)\end{array}$ & $\begin{array}{l}-.3904 \\
(8.17)\end{array}$ & $\mathrm{n} / \mathrm{a}$ \\
\hline Great Britain & $\begin{array}{l}-.1231 \\
(2.55)\end{array}$ & $\begin{array}{l}-.1412 \\
(2.16)\end{array}$ & $\begin{array}{l}-.1031 \\
(1.40)\end{array}$ & $\begin{array}{l}-.0980 \\
(2.03)\end{array}$ & $\begin{array}{l}-.1065 \\
(2.19)\end{array}$ & $\mathrm{n} / \mathrm{a}$ \\
\hline Hungary & $\begin{array}{l}-1.0946 \\
(21.54)\end{array}$ & $\begin{array}{l}-1.0500 \\
(16.43)\end{array}$ & $\begin{array}{l}-1.2126 \\
(14.19)\end{array}$ & $\begin{array}{l}-1.1122 \\
(21.85)\end{array}$ & $\mathrm{n} / \mathrm{a}$ & - \\
\hline Netherlands & $\begin{array}{l}-.2018 \\
(4.47)\end{array}$ & $\begin{array}{l}-.2147 \\
(3.44)\end{array}$ & $\begin{array}{l}-.1755 \\
(2.55)\end{array}$ & $\begin{array}{l}-.1961 \\
(4.31)\end{array}$ & $\begin{array}{l}-.2006 \\
(4.38)\end{array}$ & $\mathrm{n} / \mathrm{a}$ \\
\hline Italy & $\begin{array}{c}-.8122 \\
(15.86)\end{array}$ & $\begin{array}{c}-.8222 \\
(12.46)\end{array}$ & $\begin{array}{l}-.8047 \\
(9.78)\end{array}$ & $\begin{array}{l}-.8143 \\
(15.89)\end{array}$ & $\begin{array}{c}-.8234 \\
(15.88)\end{array}$ & $\mathrm{n} / \mathrm{a}$ \\
\hline Eire & $\begin{array}{l}.0863 \\
(1.70)\end{array}$ & $\begin{array}{l}.1638 \\
(2.42)\end{array}$ & $\begin{array}{l}.0149 \\
(0.19)\end{array}$ & $\begin{array}{l}.1165 \\
(2.28)\end{array}$ & $\begin{array}{l}.1127 \\
(2.18)\end{array}$ & $\mathrm{n} / \mathrm{a}$ \\
\hline Northern Ireland & $\begin{array}{l}-.0090 \\
(0.17)\end{array}$ & $\begin{array}{c}.1081 \\
(1.47)\end{array}$ & $\begin{array}{l}-.1142 \\
(1.38)\end{array}$ & $\begin{array}{c}.0111 \\
(0.21)\end{array}$ & $\begin{array}{l}.0025 \\
(0.05)\end{array}$ & $\mathrm{n} / \mathrm{a}$ \\
\hline Poland & $\begin{array}{l}-.9233 \\
(17.72)\end{array}$ & $\begin{array}{c}-.8681 \\
(12.85)\end{array}$ & $\begin{array}{r}-.9875 \\
(11.89)\end{array}$ & $\begin{array}{l}-.9003 \\
(17.25)\end{array}$ & $\mathrm{n} / \mathrm{a}$ & $\begin{array}{l}.1752 \\
(3.23)\end{array}$ \\
\hline Slovenia & $\begin{array}{l}-1.2245 \\
(27.63)\end{array}$ & $\begin{array}{l}-1.2372 \\
(21.79)\end{array}$ & $\begin{array}{c}-1.2220 \\
(16.89)\end{array}$ & $\begin{array}{l}-1.2226 \\
(27.56)\end{array}$ & $\mathrm{n} / \mathrm{a}$ & $\begin{array}{l}-.1301 \\
(2.85)\end{array}$ \\
\hline Philippines & $\begin{array}{l}-.4325 \\
(8.74)\end{array}$ & $\begin{array}{l}-.4144 \\
(6.58)\end{array}$ & $\begin{array}{l}-.4701 \\
(5.81)\end{array}$ & $\begin{array}{l}-.4343 \\
(8.77)\end{array}$ & $\begin{array}{l}-.4492 \\
(8.92)\end{array}$ & $\mathrm{n} / \mathrm{a}$ \\
\hline New Zealand & $\begin{array}{l}-.2824 \\
(5.63)\end{array}$ & $\begin{array}{l}-.2678 \\
(4.24)\end{array}$ & $\begin{array}{l}-.2986 \\
(3.58)\end{array}$ & $\begin{array}{l}-.2836 \\
(5.65)\end{array}$ & $\begin{array}{l}-.2884 \\
(5.71)\end{array}$ & $\mathrm{n} / \mathrm{a}$ \\
\hline Norway & $\begin{array}{l}-.4417 \\
(9.40)\end{array}$ & $\begin{array}{l}-.4662 \\
(7.87)\end{array}$ & $\begin{array}{l}-.3958 \\
(5.08)\end{array}$ & $\begin{array}{l}-.4459 \\
(9.48)\end{array}$ & $\begin{array}{l}-.4537 \\
(9.57)\end{array}$ & $\mathrm{n} / \mathrm{a}$ \\
\hline Israel & $\begin{array}{l}-.8190 \\
(15.83)\end{array}$ & $\begin{array}{c}-.6870 \\
(10.36)\end{array}$ & $\begin{array}{l}-.9931 \\
(11.87)\end{array}$ & $\begin{array}{c}-.7888 \\
(15.21)\end{array}$ & $\begin{array}{l}-.7774 \\
(14.85)\end{array}$ & $\mathrm{n} / \mathrm{a}$ \\
\hline East Germany & $\begin{array}{c}-.8258 \\
(17.81)\end{array}$ & $\begin{array}{l}-.8425 \\
(14.45)\end{array}$ & $\begin{array}{l}-.8258 \\
(10.62)\end{array}$ & $\begin{array}{l}-.8114 \\
(17.46)\end{array}$ & $\mathrm{n} / \mathrm{a}$ & $\begin{array}{l}.2898 \\
(6.00)\end{array}$ \\
\hline
\end{tabular}


Table 6. Continued

\begin{tabular}{|c|c|c|c|c|c|c|}
\hline Variable/Country & $\begin{array}{l}\text { All } \\
\text { (I) }\end{array}$ & $\begin{array}{l}\text { Employed } \\
\text { (2) }\end{array}$ & $\begin{array}{c}\text { Not } \\
\text { Employed } \\
\text { (3) }\end{array}$ & $\begin{array}{l}A l l \\
\text { (4) }\end{array}$ & $\begin{array}{c}\text { Capitalist } \\
\text { (5) }\end{array}$ & $\begin{array}{c}\text { Ex- } \\
\text { Communist } \\
\text { (6) }\end{array}$ \\
\hline Unemployed & - & - & - & $\begin{array}{l}-.4549 \\
(11.24)\end{array}$ & $\begin{array}{l}-.4995 \\
(9.89)\end{array}$ & $\begin{array}{l}-.3583 \\
(5.27)\end{array}$ \\
\hline Out of the Labor Force & - & - & - & $\begin{array}{l}-.0424 \\
(1.86)\end{array}$ & $\begin{array}{l}-.0452 \\
(1.70)\end{array}$ & $\begin{array}{l}-.0360 \\
(0.75)\end{array}$ \\
\hline Threshold 1 & -2.4193 & -2.5888 & -2.3017 & -2.5224 & -2.4040 & -1.4934 \\
\hline Threshold 2 & -1.2745 & -1.3891 & -1.1936 & -1.3687 & -1.4735 & -.1064 \\
\hline Threshold 3 & .6072 & .5758 & .5845 & .5221 & .4700 & 1.6800 \\
\hline $\mathrm{Chi}^{2}$ & 2780 & 1503 & 1325 & 2907 & 1110 & 402 \\
\hline $\mathrm{N}$ & 16529 & 9733 & 6796 & 16529 & 11655 & 4874 \\
\hline Pseudo $\mathrm{R}^{2}$ & .0820 & .0787 & .0901 & .0858 & .0502 & .0393 \\
\hline \multicolumn{7}{|l|}{ Separate Equations } \\
\hline Ex-Communist Dummy & $\begin{array}{c}-.8439 \\
(28.58)\end{array}$ & $\begin{array}{l}-.7082 \\
(26.88)\end{array}$ & $\begin{array}{c}-.7322 \\
(22.36)\end{array}$ & $\begin{array}{l}-.8348 \\
(28.23)\end{array}$ & $\mathrm{n} / \mathrm{a}$ & $\mathrm{n} / \mathrm{a}$ \\
\hline
\end{tabular}

Notes: the United States is the excluded category in columns 1-5. Hungary is excluded in column 6.

Source: ISSP (1991).

gender variable in equation 6 and the higher levels of happiness of those age $65-74$ in equation 5 compared with the middle-aged. Individuals living in ex-communist countries report lower levels of happiness and, if employed, lower levels of job satisfaction than are found in our control group of Western countries. This is further confirmation of the legacy hypothesis.

\section{Attitudes Toward Unions}

One interpretation of the results on job satisfaction is that it is a legacy of transmission belt unions and the absence of a free labor market. If the lack of independent voice is, in fact, an important factor, we would expect to see Hungarians and persons in other ex-communist countries differ from people in Western countries in their attitudes toward trade unions.

The 1990 and 1993 ISSP contains several questions about attitudes toward unionism that enable us to test that interpretation. Table 7 records the responses of Hungarians, Bulgarians, and Czechs as well as ISSP respondents from Western countries to questions regarding unionism in those sur- veys. The responses to the question "How good are trade/labor unions for the country as a whole?" show that persons in the excommunist countries had less favorable views of unions in their country than did Westerners. Forty-two percent of Hungarians, $45 \%$ of Bulgarians, and $37 \%$ of Czechs reported that unions were "not very good" or "not good at all," compared to $16 \%$ of West Germans, $27 \%$ of the British respondents, $25 \%$ of American respondents, and so on.

A large number of Italians (44\%) also reported that unions were "not very good" or "not good at all." But the reason for the dissatisfaction with unions in ex-communist countries differs markedly from the reason for Italian dissatisfaction. Asked "Do you think that trade unions have too much power or too little power?", the eastern Europeans overwhelmingly thought that unions had too little power, whereas Italians disapproved of unions as having too much power (responses to question 2). Moreover, the proportion of Hungarians who expressed the belief that strong trade unions are needed to protect workers (question 3) exceeded 
Table 7. Perceptions of the Role of Trade Unions in Nine Countries, 1990 and 1993.

(Q1) "How good are trade/labor unions for the country as a whole?" (1990: V45 and 1993 preliminary for Bulgaria \& Czech Republic)

\begin{tabular}{|c|c|c|c|c|c|c|c|c|c|c|c|}
\hline \multirow[b]{2}{*}{ Response } & \multirow{2}{*}{\multicolumn{3}{|c|}{$\begin{array}{c}\text { Crech } \\
\text { ia Republic } \\
1993\end{array}$}} & \multicolumn{2}{|c|}{ Unweighted Means } & \multirow[b]{2}{*}{$\begin{array}{c}\text { West } \\
\text { Germany } \\
1990\end{array}$} & \multirow[b]{2}{*}{$\begin{array}{c}G B \\
1990\end{array}$} & \multirow[b]{2}{*}{$\begin{array}{l}\text { USA } \\
1990\end{array}$} & \multirow[b]{2}{*}{$\begin{array}{c}\text { Norway } \\
1990\end{array}$} & \multirow[b]{2}{*}{$\begin{array}{l}\text { Israel } \\
1990\end{array}$} & \multirow[b]{2}{*}{$\begin{array}{l}\text { Italy } \\
1990\end{array}$} \\
\hline & & & & $\begin{array}{c}\text { Ex- } \\
\text { Communist } \\
1990+1993\end{array}$ & $\begin{array}{c}\text { Capilalist } \\
1990\end{array}$ & & & & & & \\
\hline Excellent & 2.7 & 10.1 & 4.0 & 5.6 & 3.3 & 5.7 & 2.0 & 2.9 & 3.7 & 3.3 & 1.9 \\
\hline Very Good & 30.4 & 21.4 & 15.6 & 22.5 & 17.3 & 26.0 & 15.7 & 17.2 & 21.9 & 15.2 & 7.9 \\
\hline Fairly Good & 25.1 & 23.1 & 57.6 & 35.3 & 53.5 & 53.3 & 55.3 & 54.3 & 58.6 & 53.1 & 46.5 \\
\hline Not Very Good & 26.6 & 21.2 & 18.8 & 22.2 & 19.9 & 13.2 & 20.7 & 19.7 & 12.2 & 21.3 & 32.4 \\
\hline Not Good at All & 15.2 & 24.2 & 3.9 & 14.4 & 6.0 & 1.8 & 6.2 & 5.7 & 3.6 & 7.1 & 11.3 \\
\hline $\mathrm{N}$ & 782 & 822 & 865 & 2469 & 7189 & 2303 & 971 & 943 & 1271 & 750 & 951 \\
\hline
\end{tabular}

(Q2) "Do you think that trade/labor unions in this country have too much power?" (1990: V42 and 1993 preliminary for Bulgaria \& Czech Republic)

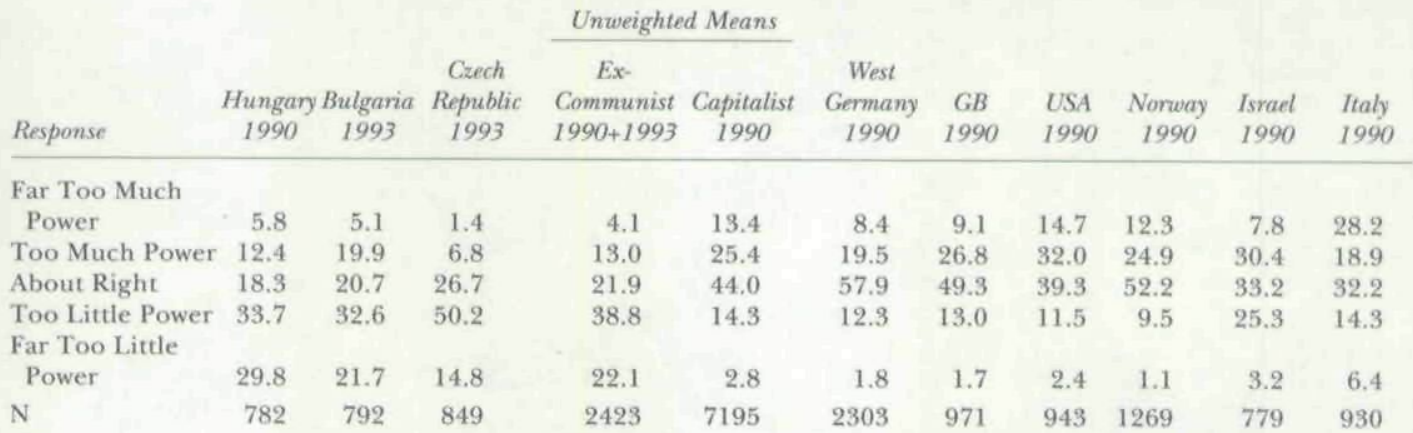

(Q3) "Workers need strong trade unions to protect their interests" (1989: V23)

\begin{tabular}{|c|c|c|c|c|c|c|c|c|c|c|}
\hline Response & Hungary & $\begin{array}{c}\text { Capitalist } \\
\text { Unweighted } \\
\text { Mean }\end{array}$ & $\begin{array}{c}\text { West } \\
\text { Germany }\end{array}$ & $G B$ & USA & Austria & Norway & $\begin{array}{l}\text { Nether- } \\
\text { lands }\end{array}$ & Israel & Haly \\
\hline Strongly Agree & 28.8 & 21.3 & 31.5 & 12.1 & 10.6 & 24.4 & 23.7 & 17.7 & 24.2 & 26.6 \\
\hline Agree & 47.4 & 39.8 & 41.7 & 29.6 & 25.5 & 49.0 & 41.2 & 48.2 & 42.8 & 39.0 \\
\hline Neither & 12.0 & 18.8 & 15.4 & 23.2 & 26.2 & 11.0 & 19.2 & 22.5 & 16.2 & 17.0 \\
\hline Disagree & 10.0 & 15.0 & 9.1 & 28.8 & 25.4 & 12.2 & 11.1 & 9.1 & 12.2 & 13.0 \\
\hline Strongly Disagree & 1.8 & 5.1 & 2.3 & 6.3 & 12.3 & 3.3 & 4.8 & 2.6 & 4.7 & 4.3 \\
\hline $\mathrm{N}$ & 880 & 18273 & 1288 & 1085 & 1231 & 1631 & 1652 & 1487 & 1003 & 946 \\
\hline
\end{tabular}

Source: ISSP $(1990,1993)$.

that in all Western countries except Germany. ${ }^{15}$

\footnotetext{
${ }^{15} \mathrm{We}$ initially expected one additional ISSP question-"In general, how would you describe relations at your workplace between management and employees?" - to be informative on possible attitudes toward the need for unions. But the response of Hungarians relative to Westerners here was ambiguous. A much smaller proportion $(11.5 \%)$ stated that labor-management relations were very good than in any Western country (the Netherlands was the next lowest at
}

Why do persons from ex-communist eastern European countries and Westerners respond so differently to the union questions in the ISSP? How can we rationalize the view of workers in ex-communist coun-

$18.5 \%$ ), but at the same time, the proportion of Hungarians describing labor relations as quite or very bad $(3.1 \%)$ was much smaller than the proportion of workers in Western countries (the next lowest was Israel, with $4 \%$ ). 
Table 8. Percentages Who Strongly Favor Government Intervention in the Labor Market: Seven Ex-Communist Countries and Fifteen Capitalist Countries, Various Years.

\begin{tabular}{|c|c|c|c|c|c|c|c|c|}
\hline \multirow[b]{2}{*}{ Country } & \multicolumn{3}{|c|}{$\begin{array}{c}\text { Reduce } \\
\text { Income Differences }\end{array}$} & \multirow{2}{*}{$\begin{array}{c}\text { Control Wages } \\
\text { by Law } \\
1990\end{array}$} & \multicolumn{2}{|c|}{$\begin{array}{l}\text { Provide Jobs } \\
\text { for All } \\
\end{array}$} & \multicolumn{2}{|c|}{$\begin{array}{l}\text { Provide Basic } \\
\text { Income for All }\end{array}$} \\
\hline & 1987 & 1992 & 1993 & & 1987 & 1992 & 1987 & 1992 \\
\hline \multicolumn{9}{|l|}{ Ex-Communist } \\
\hline Bulgaria & & 61 & 63 & & 70 & & & 77 \\
\hline Czechoslovakia & & 23 & 34 & & & 36 & & 30 \\
\hline East Germany & & 42 & 39 & 50 & & 55 & & 50 \\
\hline Hungary & 32 & 33 & 38 & 16 & 45 & 52 & 40 & 51 \\
\hline Poland & 36 & 30 & 38 & & 72 & 50 & & 47 \\
\hline Russia & & 39 & 32 & & & 75 & & 71 \\
\hline Slovenia & & 31 & 32 & & & 36 & & 27 \\
\hline Unweighted Mean & 34 & 33 & 39 & 33 & 62 & 51 & 40 & 50 \\
\hline \multicolumn{9}{|l|}{ Capitalist } \\
\hline Australia & & 10 & & & & 10 & & 13 \\
\hline Austria & 35 & 27 & & & 36 & 31 & 20 & 13 \\
\hline Canada & & 17 & 12 & & & 16 & & 19 \\
\hline Great Britain & 21 & 27 & 22 & 6 & 24 & 21 & 20 & 28 \\
\hline Israel & & & 32 & 24 & & & & \\
\hline Italy & & 40 & 29 & 21 & & 57 & & 37 \\
\hline Japan & & & 30 & & & & & \\
\hline Netherlands & 17 & & 13 & & 23 & & 10 & \\
\hline New Zealand & & 16 & 15 & & & 19 & & 21 \\
\hline Norway & & 17 & 15 & 7 & & 37 & & 35 \\
\hline Spain & & & 19 & & & & & \\
\hline Sweden & & 16 & & & & 26 & & 9 \\
\hline Switzerland & 11 & & & & 17 & & 12 & \\
\hline USA & 8 & 10 & 7 & 7 & 17 & 17 & 7 & 10 \\
\hline West Germany & 17 & 20 & 23 & 9 & 35 & 22 & 17 & 19 \\
\hline Unweighted Mean & 18 & 20 & 20 & 12 & 25 & 26 & 14 & 20 \\
\hline
\end{tabular}

Source: ISSP $(1987,1990,1992,1993)$.

tries that unions are not good for the country, are too weak, and are needed to protect workers? Our explanation is that these responses reflect two aspects of the experience with unions under communism: the past role of unions as transmission belts of the state, and the weakness of newly emerging or changing traditional unions-one of several legacies of the country's communist labor system.

\section{Attitudes Toward the State in Economic Life}

Under communism, the state dominated economic life, with adverse consequences for economic progress and for worker and citizen satisfaction. By overturning communism, these countries have committed themselves to developing a market economy with a much smaller governmental role in economic affairs than in their past. Still, the decades of government-dominated economic life and communist egalitarian ideology may have left a legacy of "statism" in these countries that would produce attitudes toward state interventions in wage and employment different from those found among people brought up in market economies.

Table 8 presents responses to ISSP questions from the 1987, 1990, 1992, and 1993 modules that cast light on this issue. It shows a wide difference in attitudes toward state interventions between eastern European and Western countries, and some differences among the ex-communist countries as well. The figures under the heading 
"Reduce Income Differences" show that a larger proportion of workers in the former communist countries than in the capitalist countries believe that the government is responsible for reducing differences in income. In 1987, $34 \%$ of persons in the two ex-communist countries for which we have data, Hungary and Poland, strongly agreed with this statement, proportions that far exceed those in Western countries save for Austria. In 1992, for which we have information for seven ex-communist countries, the results are similar. On average, $33 \%$ of people in the ex-communist countries agreed strongly that governments should reduce income differences, compared to just $20 \%$ in the capitalist countries (though many in the capitalist countries agreed somewhat). The sole countries whose responses overlap those in the other set of countries in this contrast are Italy and Austria among the Western countries and Czechoslovakia among the ex-communist countries. The figures for 1993 show an even greater divergence between the excommunist and the capitalist countries, with no overlap at all!

There is less consistency among the former communist countries in whether respondents support controlling wages by law. The East Germans strongly favor such controls, but the Hungarians do not. The contrast between the East and West Germans on this issue is striking.

On the employment side, the ISSP asked in 1987 and in 1992 whether the government should provide jobs for all. The respondents in the two eastern European countries covered in 1987, Hungary and Poland, were far more likely to agree with this proposition than were respondents in the Western countries. In 1992, when the ISSP asked this same question in six excommunist countries, the unweighted average proportion of persons in those countries who agreed strongly was $51 \%$, compared to $26 \%$ in the capitalist countries.

The greater support for government playing a role in income and employment determination in former communist countries shows up, finally, in responses to the following question: "Should government provide basic income for all?" Only Hungary provided data on this question in 1987. There, the proportion strongly agreeing was $40 \%$, far above the corresponding proportion in capitalist countries. The difference in 1992, for which we have data for seven ex-communist countries, is even greater.

In sum, while there are some country differences, the overwhelming pattern in these data is a greater proclivity for relying on the state ${ }^{16}$ among persons from ex-communist countries than among Westernersconsistent with the legacy hypothesis.

\section{Conclusions}

We have uncovered substantial differences between survey respondents in former communist countries and those in Western countries in responses to diverse questions about attitudes toward earnings inequality, job satisfaction, working conditions, unions, and the role of the state in regulating labor market outcomes. In ISSP surveys conducted over the years 1987-93, the citizens of former communist countries evinced a greater desire for egalitarianism, less satisfaction with their jobs, more support for strong unions, and more support for state intervention than did most Westerners. At the same time, as perceived occupational earnings differentials widened in these countries over the course of the breakdown of communism and the transition to more capitalistic systems between 1987 and 1992, tolerance for those differentials increased substantially. Without gainsaying the important differences in outcomes and attitudes among ex-communist countries and among Western countries, we believe that it is reasonable to interpret the broad pattern of differences between the two groups as reflecting a legacy of communist economics.

\footnotetext{
${ }^{16}$ Frentzel-Zagorska and Zagorski's (1993) analysis of Polish public opinion polls gave results that are consistent with ours. Table 7 in Rose and Haerpfer (1994) also shows substantial "collectivist values" in eastern European countries, though with variation among countries and questions.
} 
Appendix Table A1

Responses to the ISSP, 1987-1992

\begin{tabular}{|c|c|c|c|c|c|c|c|}
\hline Country & 1987 & 1989 & 1990 & 1991 & 1992 & 1993 & $A l l$ \\
\hline \multicolumn{8}{|l|}{ Ex-Communist: } \\
\hline Bulgaria & & & & & 1198 & 1183 & 2381 \\
\hline Czechoslovakia & & & & & 1101 & 1005 & 2106 \\
\hline East Germany & & & 1028 & 1486 & 1094 & 1092 & 4700 \\
\hline Hungary & 2606 & 1000 & 977 & 1000 & 1250 & 1167 & 8000 \\
\hline Poland & 3943 & & & 1063 & 1636 & 1641 & 8283 \\
\hline Russia & & & & & 1983 & 1931 & 3914 \\
\hline Slovenia & & & & 2080 & 1049 & 1032 & 4161 \\
\hline \multicolumn{8}{|l|}{ Capitalist: } \\
\hline Australia & 1574 & 2398 & & & 2203 & & 6175 \\
\hline Austria & 972 & 1997 & & & 1027 & & 3996 \\
\hline Canada & & & & & 1004 & 1467 & 2471 \\
\hline Eire & & 972 & 1005 & 1005 & & 957 & 3939 \\
\hline Great Britain & 1212 & 1297 & 1197 & 1257 & 1066 & 1261 & 7290 \\
\hline Israel & & 1133 & 991 & 991 & & 1198 & 4313 \\
\hline Italy & 1027 & 1028 & 983 & 983 & 996 & 1000 & 6017 \\
\hline Netherlands & 1638 & 1690 & & 1635 & & 1852 & 6815 \\
\hline New Zealand & & & & 1070 & 1299 & 1271 & 3580 \\
\hline Norway & & 1848 & 1517 & 1506 & 1538 & 1414 & 7823 \\
\hline Sweden & & & & & 749 & 1414 & 2163 \\
\hline Switzerland & 987 & & & & & & 987 \\
\hline USA & 1564 & 1453 & 1217 & 1359 & 1273 & 1557 & 8423 \\
\hline West Germany & 1397 & 1575 & 2812 & 1346 & 2297 & 1014 & 10441 \\
\hline Total & 16920 & 16391 & 11727 & 16781 & 22703 & 25969 & 107978 \\
\hline
\end{tabular}

Notes: Data for 1993 were obtained from the ISSP 1993 Source book (ZA Study 2450). Data are also available in the ISSP (but not used in this paper) for Northern Ireland and the Philippines for a number of years and Spain and Japan for 1993 only.

\section{REFERENCES}

Akerlof, George, Andre Rose, Janet Yellen, and Helga Hessenius. 1991. "East Germany in from the Cold: The Economic Aftermath of Currency Union." Brookings Papers on Economic Activity, Vol. 1, pp. 1-88. Blanchflower, David G., and Richard B. Freeman. 1992. "Going Different Ways: Unionism in the U.S. and Other OECD Countries." Industrial Relations, Vol. 31, No. 1 (Winter), pp. 56-79. Reprinted in Labor Market Institutions and the Future Role of Unions, edited by M. Bognanno and M. Kleiner. London: Blackwell, 1992.

Blanchflower, David G., and Andrew J. Oswald. 1989. "International Patterns of Work." In R. Jowell and S. Witherspoon, eds., British Social Attitudes: International Comparisons. Brookfield, Vt.: Gower. Press.

1994. The Wage Curve. Cambridge, Mass.: MIT

1992. "Entrepreneurship and Supernormal Returns: Evidence from Britain and the US." NBER Working Paper No. 4228.

Borjas, George J. 1979. "Job Satisfaction, Wages, and Unions." Journal of Human Resources, Vol. 14, No. 1, pp. 21-40.
Burawoy, Michael. 1985. The Politics of Production: Factory Regimes Under Capitalism and Socialism. London: Verso Press.

Burawoy, Michael, and Janos Lukacs. 1992. The Radiant Past: Ideology and Reality in Hungary's Road to Capitalism. Chicago: University of Chicago Press.

Clark, Andrew E., and Andrew J. Oswald. 1997. "Satisfaction and Comparison Income." Journal of Public Economics, forthcoming.

Freeman, Richard B. 1978. "Job Satisfaction as an Economic Variable." American Economic Review, Vol. 68 , No. 1, pp. 135-41. 1992. "Getting Here from There: Labor in the Transition to a Market Economy." In Bertram Silverman, Robert Vogt, and Murray Yanowitch, eds., Labor and Democracy in the Transition to a Market System: A U.S.-Post-Soviet Dialogue. New York: M.E. Sharpe.

1994. "What Direction for Labor Market Institutions in Eastern and Central Europe?" In Olivier Blanchard, Kenneth Froot, and Jeffrey Sachs, eds., The Transition in Eastern Europe, Vol. 2. Chicago: University of Chicago Press. 
Frentzel-Zagorska, Janina, and Krysztof Zagorski. 1993. "Polish Public Opinion on Privatisation and State Interventionism." Europe-Asia Studies, Vol. 45, No. 4 (July), pp. 705-24.

Hamermesh, Daniel S. 1977. "Economic Aspects of Job Satisfaction." In Orley Ashenfelter and W. Oates, eds., Essays in Labor Market Analysis. New York: John Wiley.

Haraszti, Miklos. 1978. A Worker in a Worker's State. New York: Universe Books.

Hofstede, Geert. 1985. Culture's Consequences: International Differences in Work-Related Values. London: Sage.

Kohn, Melvin L. 1989. “Cross-National Research as an Analytic Strategy," In M. Kohn, ed., Cross-National Research in Sociology. Newbury Park, Calif.: Sage.

Kornai, Janos. 1980. The Economics of Shortage. Amsterdam: North-Holland.

Locke, Edwin A. 1969. "What Is Job Satisfaction?" Organizational Behavior and Human Performance, Vol.
4, pp. 309-36.

Oswald, A. J. 1994. "The Unemployment Puzzle." Mimeo, Centre for Economic Performance.

Rose, Richard, and Christian Haerpfer, 1994. "Mass Response to Transformation in Post-Communist Societies." Europe-Asia Studies, Vol. 46, No. 1 (January), pp. 3-28.

Shiller, Robert J., Maxim Boycko, and Vladimir Korobov. 1991. "Popular Attitudes Toward Free Markets: The Soviet Union and the United States Compared." American Economic Review, Vol. 81, No. 3, pp. 385-400.

1992. "Hunting for Homo Sovieticus: Situational Versus Attitudinal Factors in Economic Behavior," Brookings Papers on Economic Activity, Vol. 1, pp. 127-82.

Wilensky, Harold. 1966. "Work as a Social Problem." In Howard Saul Becker, ed., Social Problems: A Modern Approach. New York: Wiley, pp. 11766. 
Copyright of Industrial \& Labor Relations Review is the property of Cornell University. The copyright in an individual article may be maintained by the author in certain cases. Content may not be copied or emailed to multiple sites or posted to a listserv without the copyright holder's express written permission. However, users may print, download, or email articles for individual use. 